\title{
Therapeutic Effect of Hydro-Ethanolic Extract of Pothos scandens L on key Carbohydrate Metabolizing Enzymes and Xenobiotic Marker Enzymes in DMBA Induced Experimental Mammary Carcinoma
}

\author{
Jethinlalkhosh Jayapalan Prasannakumari ${ }^{1 *}$, Praveena Padmam², Victor Arokia Doss ${ }^{3}$ \\ ${ }^{1}$ Research and Development Centre, Bharathiar University, Coimbatore -641046, Tamil Nadu, INDIA. \\ 2Department of Biotechnology Engineering, Sahrdaya College of Engineering and Technology, Thrissur, Kerala, INDIA. \\ ${ }^{3}$ Department of Biochemistry, P S G College of Arts and Science, Coimbatore - 641014, Tamil Nadu, INDIA.
}

\begin{abstract}
Objective: In the present study, phytochemical evaluation and the therapeutic effect of $50 \%$ hydro-ethanolic extract of aerial parts of Pothos scandens (HEEPS) on glycolytic enzymes, TCA cycle enzymes, gluconeogenic enzymes and xenobiotic marker enzymes in the liver and breast tissues of 7, 12 -Dimethylbenz [a] anthracene (DMBA) induced breast cancer bearing rats were carried out. Materials and Methods: Five groups of (each group six rats) female albino Spargue-Dawley rats were taken. Group I (control), Group II (DMBA induced, $20 \mathrm{mg} / \mathrm{kg}$ b.wt p.o), Group III (DMBA + Cyclophoshamide, 10mg/kg b.wt p.o), Group IV (DMBA $+200 \mathrm{mg} / \mathrm{kg}$ b.wt p.o of HEEPS) and Group V (DMBA $+400 \mathrm{mg} / \mathrm{kg}$ b.wt p.o of HEEPS). The alteration in the level of carbohydrate metabolizing enzymes such as Hexokinase, Phosphogluco isomerase, Glucose-6-phosphatase, Fructose-1,6-bis phosphatase, Succinate dehydrogenase and Malate dehydrogenase together with the level of xenobiotic markers like Cytochrome $\mathrm{P} 450$ reductase, Cytochrome $\mathrm{C}$ oxidase and Glutathione -S- transferase were analyzed in all the groups. GC-MS analysis of the plant extract was also carried out. Results: Increased level of glycolytic enzymes, decreased level of TCA cycle enzymes, gluconeogenic enzymes and altered level of xenobiotic marker enzymes observed in Group II was brought to near normal in treatment groups in a dose dependent manner suggesting potential anticancer activity of HEEPS. This was supported by the GC-MS analysis of the plant extract which revealed the presence of many compounds with anticancer activity. Conclusion: The study revealed that HEEPS is effective in restoring the activity of mitochondria in DMBA induced breast cancer.
\end{abstract}

Key words: Pothos scandens L, GC-MS, 7, 12 -Dimethylbenz [a] anthracene (DMBA), Mammary Carcinoma, Carbohydrate Metabolizing Enzymes, Xenobiotic Markers.

\section{INTRODUCTION}

Cancer can be described as a group of more than 100 different diseases which are characterized by uncontrolled cellular growth, local tissue invasion and distant metastasis. ${ }^{1}$ Cancer claims over 6 million lives every year and it continues to represent the largest cause of mortality in the world. ${ }^{2}$ Breast cancer is the most common form of cancer and the leading cause of cancer mortality among women worldwide., ${ }^{3,4}$ The number of new breast cancer cases in India is about 100,000 per year. ${ }^{5}$ It is a major clinical problem that possesses significant social and economic challenges to the health care system. ${ }^{6}$ Breast cancer is a collection of breast diseases that have diverse genomic variations histopathologies and clinical outcomes. ${ }^{7}$

Mitochondrial dysfunction, rapid growth and cellular proliferation are hallmarks of tumor cells. In order to support continuous cell growth and proliferation in a hypoxic
Submission Date: 18-01-2017; Revision Date: 14-03-2017; Accepted Date: 18-03-2017

DOI: 10.5530/ijper.51.3.70 Correspondence:

Jethinlalkhosh J P, Quality Control Section, Food Corporation of India, District Office, Palakkad - 678731, Kerala, INDIA.

Phone no: +919633860543 E mail: mailjethin@gmail. com

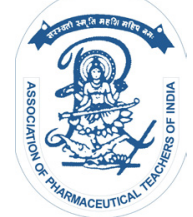

www.ijper.org 
and acidic conditions generated during progressive tumor cell growth, cancer cells alter their metabolism by shifting the burden of energy metabolism from mitochondrial oxidative phosphorylation to glycolysis. ${ }^{8}$ Molecular defects in mitochondrial or nuclear genes that code for proteins that are involved in mitochondria biogenesis; respiratory maintenance of membrane potential; chain assembly and function and energy metabolic or signal transducing pathways can be the cause of mitochondrial dysfunction. ${ }^{9}$ Despite various therapeutic strategies including chemotherapy to treat cancer, drug resistance and high systemic toxicity limit the successful outcomes in most cases. Moreover cancer treatment is usually accompanied by diverse side effects to different body organs. ${ }^{10}$ Hence there is a global trend to go back to natural resources (medicinal plants) which are more therapeutically effective, culturally acceptable and economically affordable. ${ }^{11}$ Phytochemicals with anticancer potential which interfere with carcinogenesis makes them interesting tools in cancer research. ${ }^{12}$

Pothos scandens (P. scandens), a medicinal aroid, is a climbing shrub with aerial roots growing on trees and rocks like ivy which belongs to the family Araceae. After being fried in oil, the bruised root of the plant is applied to promote healing of abscesses. An infusion of the leaves of this plant is used by the Indian people as a bath for curing convulsions and epilepsy. Apart from that, the stem is also widely used to treat asthma. It has been also reported that the whole plant is used against various health problems and disorders such as diarrhea ${ }^{13}$, small pox $^{14}$, muscle catches, sprains ${ }^{15}$ and bone fracture. ${ }^{16}$ Recently, the ethanolic extract of P. scandens has been reported to be effective in wound healing ${ }^{17}$ and the plant has also been reported to have significant antioxidant and antipyretic activity. ${ }^{18}$ The ethanolic extracts of aerial part of P. scandens showed the presence of phytochemicals such as alkaloids, glycosides, flavonoids and phenolic compounds and has been shown to inhibit mast cell derived immediate-type allergic reactions and mast cell degranulation. ${ }^{19}$ The methanolic extract of leaves of $P$. scandens has been reported to have cytotoxic as well as thrombolytic potential. ${ }^{20}$ From the literature survey it was found that the phytochemical analysis of leaf extract of P. scandens showed the presence of alkaloid, catachin, coumarin, flavonoid, phenolics, saponins, sugar, glycoside, xanthoprotein ${ }^{21}$ and phytosterols. $.^{18} 1,2$ - Benzenedicarboxylic acid, diisooctylester; $n$-Hexadecanoic acid, 9,12,15-Octadecatrienoic acid, (ZZZ)-; Octadecanoic acid; Phytol and 9,12 Octadecadienoic acid (ZZ) were detected as major compounds in the GC-MS analysis of the ethanolic extract of P. scandens leaf. ${ }^{22}$
As per the ethnobotanical data collected during the field surveys made on several visits between 2004 and 2006 to three Akha communities in Chiang Rai in northern Thailand, it was found that the whole aerial parts of $P$. scandens were used by the traditional healers to treat cancer. ${ }^{23}$ However, on thorough literature survey, it was found that there were no studies related to the anticancer properties of this plant. Hence, the present study aims to investigate the therapeutic properties of $P$. scandens for its potential anticancer activity by evaluating their effect on carbohydrate metabolizing enzymes and biotransformation enzymes in DMBA induced experimental mammary carcinoma.

\section{MATERIALS AND METHODS \\ Chemicals and reagents}

7, 12 -Dimethylbenz [a] anthracene (DMBA) was obtained from Sigma Chemicals Co. (St. Louis, MO, USA). All other chemicals and solvents used were of analytical grade.

\section{Plant material}

P. scandens were collected from in and around Palai, Kottayam, Kerala. They were identified and certified by the Taxonomist, Botanical Survey of India (BSI), Coimbatore, Tamil Nadu, India (Plant identification no.-BSI/ SRC/5/23/2013-14/Tech/685).

\section{Extraction Procedure}

The aerial parts of $P$. scandens were shade dried and ground to coarse powder. The coarse powder was extracted using $50 \%$ ethanol using soxhlet apparatus for 48 hours. The extracts were filtered and condensed to dryness using a rotary evaporator and stored at $-20^{\circ} \mathrm{C}$ for further studies.

\section{Animals}

Female albino Spargue-Dawley rats (150-200 g) used in the present study was procured from the animal breeding station, Mannuthy, Kerala, India. They were housed in polypropylene cages $(38 \times 23 \times 10 \mathrm{~cm})$ with not more than six animals per cage and maintained under standard environmental conditions $(14 \mathrm{~h}$ dark $/ 10 \mathrm{~h}$ light cycles; temp $25 \pm 2{ }^{\circ} \mathrm{C}$; $35-60 \%$ humidity, air ventilation) and were fed with standard pellet diet $(\mathrm{M} / \mathrm{s}$. Hindustan Lever Ltd., Mumbai, India) and fresh water ad libitum. The animals were acclimatized to the environment for two weeks prior to experimental use. Animals were fasted over night before the experimental schedule, but have free access for water ad libitum. Ethical clearance for the handling of experimental animals was obtained from the Institutional Animal Ethics Committee 
(IAEC) constituted for the purpose and care of laboratory animals as per the guidance of the Committee for the Purpose of Control and Supervision of Experiments on Animals (CPCSEA), Ministry of Social Justice and Empowerment, Government of India (IAEC No. MLEA-CPCSEA/09-2014/02).

\section{Experimental Design}

The animals were randomly divided into five groups of six animals each. Group I served as control rats. Group II rats were induced with a single dose of DMBA $(20 \mathrm{mg} /$ $\mathrm{kg}$ b. wt, dissolved in $0.75 \mathrm{ml}$ sunflower oil and $0.25 \mathrm{ml}$ physiological saline) by oral gavage at the first day of the experimental period. Group III received Cyclophoshamide (CP) $(10 \mathrm{mg} / \mathrm{kg}$ p.o), Group IV received $200 \mathrm{mg} / \mathrm{kg}$ b.wt and Group V received $400 \mathrm{mg} / \mathrm{kg}$ b.wt of HEEPS orally for 60 days after 90 days of DMBA induction. At the end of the experimental period, all the animals were anesthetized with diethyl ether, and they were sacrificed by decapitation. Animals were starved overnight before sacrifice. The breast and liver tissues were excised and rinsed 2 to 3 times in ice cold normal saline followed by $0.15 \mathrm{M}$ Tris- $\mathrm{HCl}(\mathrm{pH} 7.4)$, blotted dried and known weight of breast and liver were homogenized in $0.25 \mathrm{M}$ Tris- $\mathrm{HCl}$ buffer ( $\mathrm{pH}$ 7.5). The homogenate was subjected to differential centrifugation at $4^{\circ} \mathrm{C}$. The cell organelle such as mitochondria, microsomes and cytosolic fractions were isolated. Total homogenate and subcellular fractions were used for the assay of the following parameters in breast and liver samples.

\section{Biochemical Analysis}

The following biochemical parameters in the liver and breast tissue were analysed. Hexokinase (HK), Branstrup et al., ${ }^{24}$; Phosphogluco isomerase (PGI), Horrocks et al., ${ }^{25}$; Glucose-6-phosphatase (G-6-Pase), King ${ }^{26}$; Fructose-1, 6-bis phosphatase (F-1,6-BPase), Gancedo and Gancedo ${ }^{27}$; Succinate dehydrogenase (SDH), Slater and Bonner ${ }^{28}$; Malate dehydrogenase (MDH), Mehler et al., ${ }^{29}$; Cytochrome P450 reductase (POR), Masters et al., ${ }^{30}$; Cytochrome C oxidase (COX), Wharton and Tzagoloff ${ }^{31}$ and Glutathione -S- transferase (GST) Habig et al.,. ${ }^{32}$

\section{Gas Chromatography-Mass Spectrometry(GC-MS) analysis of hydro-ethanolic extract of $P$. scandens (HEEPS)}

GC- MS analysis of HEEPS was performed with Shimadzu GC- MS (model QP2010) operating in EI mode at $70 \mathrm{eV}$ with a Restek -5MS column $(30 \mathrm{~m} \times$ $0.25 \mathrm{~mm} \times 0.25 \mu \mathrm{m})$. Helium gas was used as carrier gas at a constant flow rate $1 \mathrm{ml} / \mathrm{min}$ and an injection volume was $1 \mu \mathrm{L}$. The oven temperature programs was initially kept at $150^{\circ} \mathrm{C}$ and hold for $1 \mathrm{~min}$, and then with a rise of $10^{\circ} \mathrm{C} /$ minute upto $250^{\circ} \mathrm{C}$ and hold for $3 \mathrm{~min}$, and again with a rise of $10^{\circ} \mathrm{C} / \mathrm{min}$ upto $280^{\circ} \mathrm{C}$ and hold for $5 \mathrm{~min}$. Injector temperature $260^{\circ} \mathrm{C}$; ion source temperature $250^{\circ} \mathrm{C}$, quadrupole temperature $150^{\circ} \mathrm{C}$, interface temperature $250^{\circ} \mathrm{C}$, full scan mode, scan range $40-600$ $\mathrm{m} / \mathrm{z}$ and solvent delay of 4 min was employed.

The interpretation of the spectrum from GC- MS analysis was done using the database of National Institute of Standard and Technology (NIST). By comparing the mass spectrum of the unknown component with the known component in the NIST library; the name, structure and molecular weight of the components of the test materials were ascertained.

\section{Statistical analysis}

The results are expressed as mean \pm standard deviation (SD).Differences between groups were assessed by oneway analysis of variance (ANOVA) using the Statistical Package of Social Sciences (SPSS, Version 16.0 for windows). The group means were compared by Duncan's Multiple Range Test (DMRT). Values were considered statistically significant when $\mathrm{p}<0.05$.

\section{RESULTS}

\section{Effect of HEEPS on carbohydrate metabolizing enzymes}

The effect of HEEPS on carbohydrate metabolizing enzymes in the liver and mammary gland tissue of mammary carcinoma bearing rats is given in Table 1 . The result indicated that the activity of glycolytic enzymes namely HK and PGI in the liver and mammary tissues of rats bearing mammary carcinoma (Group II) was significantly increased by $81.82 \%$ and $84.13 \%$ in liver and by $60 \%$ and $67.74 \%$ in mammary tissue respectively when compared with control rats (Group I). However, it was seen that the activity reverted to near normal when treated with plant extract (Group IV and Group V). The activity shown by the treatment group was almost near to those treated with standard drug (Group III).

The activity of TCA cycle enzymes like SDH and MDH were significantly lowered by $75.22 \%$ and $76.09 \%$ in liver and by $71.85 \%$ and $72.18 \%$ in mammary tissue respectively in Group II rats compared to the Group I rats. It was observed from the result that the treatment groups (Group III, Group IV and Group V) showed near normal activity of these enzymes.

Gluconeogenic enzymes like G-6-Pase and F-1, 6-BPase showed a decrease in activity by $52.86 \%$ and $51.60 \%$ in liver and by $68.72 \%$ and $48.39 \%$ in mammary tissue respectively in Group II rats when compared with control rats whereas the near normal activity was shown 


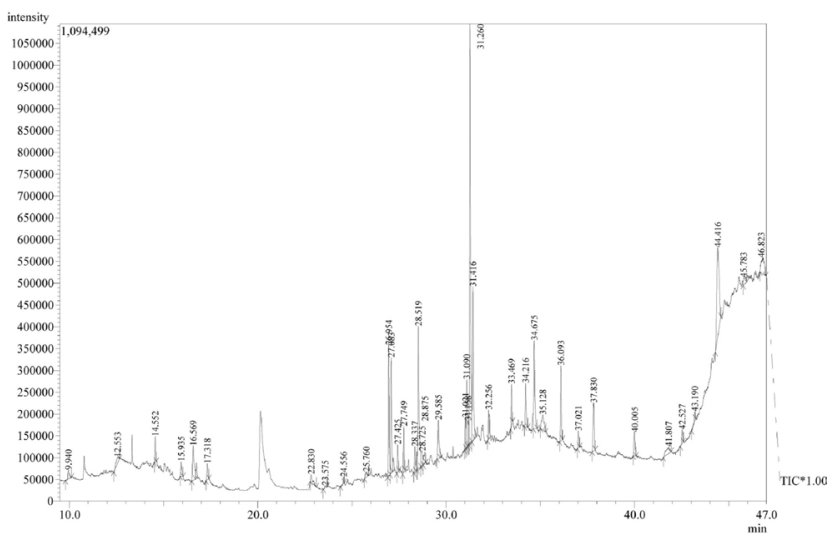

Figure 1: GC-MS chromatogram of $50 \%$ ethanolic extracts of Pothos scandens L

by Group III which was treated with standard drug and in Group IV and Group V rats treated with plant extract.

\section{Effect of HEEPS on xenobiotic marker enzymes}

Table 2 shows the effect of HEEPS on various xenobiotic marker enzymes in the liver and mammary gland tissue of mammary carcinoma bearing rats. When the rats bearing mammary carcinoma (Group II) showed a decrease in the activity of POR, COX and GST by $56.11 \%, 77.68 \%$ and $58.11 \%$ in liver and $69.14 \%$, $66.06 \%$ and $51.31 \%$ in mammary tissue respectively, the activity reached near normal in the groups treated with standard drug (Group III) and extract of P. scandens (Group IV and Group V).

\section{GC-MS analysis}

The GC-MS analysis of the HEEPS is given in Figure 1. Thirty nine compounds were revealed by the GC-MS analysis. The identified compounds with their retention time, molecular formula and molecular weight are given in Table 3. The results showed the presence of 3,7,11,15Tetramethyl-2-hexadecen-1-ol (Synonym: Phytol) 19.30\%, Stigmast-5-en-3-ol, (3 beta) (Synonym: $\beta$ Sitosterol) $9.96 \%$, Hexadecanoic acid, methyl ester $8.66 \%$, Octadecanoic acid, methyl ester 7.21\%, Hexahydrofarnesyl acetone $5.10 \%$, Dotriacontane $4.27 \%$, Hexatriacontane $3.13 \%$, 9-Octadecenoic acid (Z)-, methyl ester 2.97\%, $\alpha$ Curcumene $2.66 \%$, Cedrol $2.40 \%$, Tetrapentacontane $2.37 \%$, Ethyl heptadecanoate 2.20\%, 5-methyl-5-(4,8,12trimethyltridecyl)oxolan-2-one $2.06 \%$, Nopol $1.76 \%$, 9,12-Octadecadienoic acid (Z,Z)-, methyl ester $1.30 \%$ and Eicosane $1.29 \%$ as major compounds.

\section{DISCUSSION}

DMBA efficiently induces breast cancer in female rats. Oral delivery of DMBA to rats has been used intensively for carcinogenic studies since 1960 as a model mimicking the dietary intake of carcinogens in humans. ${ }^{33}$ It has been shown that DMBA-induced mammary carcinoma leads to disruption of redox balance of tissues which cause undesirable consequences to the mitochondrial membrane suggesting that biochemical and physiological alterations may result from oxidative damage. ${ }^{34,35}$

Non malignant cells depend primarily on mitochondrial oxidative phosphorylation (OXPHOS) than aerobic glycolysis for its energy requirement. However, Otto Warburg suggested that in contrast to non malignant cells, malignant cells depend on glycolysis rather than OXPHOS for ATP generation which is considered by some as the seventh hallmark of cancer. This could be due to the damage of mitochondrial respiration in tumor cells. ${ }^{8,36}$ In the present study, increased activity of cytosolic glycolytic enzymes in DMBA induced mammary carcinoma (Group II) suggest that DMBA induced carcinoma had lead to an alteration in carbohydrate metabolism. An increase in the rate of glycolysis confers the tumor cells with advantages like synthesis of ATP independent of oxygen; faster synthesis of ATP as compared to OXPHOS, generation of fewer reactive oxygen species and support cell proliferation by the provision of glycolytic intermediates many of which are intermediates of biosynthetic pathways. ${ }^{37,38}$ The level of hexokinase plays an important role in determining the glycolytic activity of cancer cells. ${ }^{39}$ An increase in activity of hexokinase in the Group II may be due to the consumption of large amount of glucose by cancer cells. Elevated level of PGI was reported in sarcoma and cancers in the breast. ${ }^{40}$ The elevated level of PGI observed in Group II in the present study may be due to increase in aerobic glycolysis as a result of metabolic alteration. The activity of the glycolytic enzymes reached near normal activity in groups treated plant extract in a dose dependent manner suggesting curative effect of this plant.

A decrease in the activity of TCA cycle enzymes were observed in Group II animals in the current study. The decreased activity of mitochondrial enzymes may be due to the damage to the mitochondria caused by oxidative stress which could have altered the mitochondrial membrane, morphology leading to its dysfunction ${ }^{41}$ and may be due to decrease in mitochondrial fluidity, alteration in membrane ionic permeability including proton permeability which uncouples OXPHOS from electron transport chain. ${ }^{42}$ Animals treated with extract of $P$. scandens showed significant restorative activity of mitochondria in mammary carcinoma bearing rats.

In the present study, carcinoma bearing rats showed a decrease in the activity of G-6-Pase and F-1, 6-BPase. 
Decreased activity of gluconeogenic enzymes viz G-6Pase and F-1, 6-BPase might lead to an increase in the concentration of their substrates glucose-6-phosphate and fructose-1, 6-bisphosphate. The resultant accumulated glucose-6-phosphate might be utilized for the pentose phosphate pathway to produce ribose-5-phosphate for the rapid synthesis of nucleotide in cancer bearing cells. On the other hand fructose-1, 6-bisphosphate acts as an allosteric activator of pyruvate kinase. ${ }^{43}$ The activities of these enzymes were returned to near normal when treated with plant extract suggesting a protective role of plant.
POR is a flavoenzyme ubiquitously expressed in all cells including malignant cells and catalyzes the electron transfer required for the P450 enzyme activity. ${ }^{44}$ It has been confirmed from studies that POR overexpression substantially increases the potency of prodrug mediated tumor cell killing. ${ }^{45-48}$ In the present study, a decrease in the activity of POR in both liver and breast tissues has been observed in cancer induced rats (Group II) which was brought to near normal in groups treated with plant extract. This suggests the capability of plant extract in augmenting the expression of POR.

COX is a protein present in the inner membrane of mitochondria and is responsible for the conversion of

\begin{tabular}{|c|c|c|c|c|c|}
\hline Parameter & $\begin{array}{l}\text { Group I } \\
\text { (Control) }\end{array}$ & $\begin{array}{l}\text { Group II } \\
\text { (DMBA) }\end{array}$ & $\begin{array}{c}\text { Group III } \\
(\mathrm{DMBA}+\mathrm{CP})\end{array}$ & $\begin{array}{c}\text { Group IV } \\
\text { (DMBA + HEEPS } \\
200 \mathrm{mg} / \mathrm{kgbw} \text { ) }\end{array}$ & $\begin{array}{c}\text { Group V } \\
\text { (DMBA + HEEPS } \\
400 \mathrm{mg} / \mathrm{kgbw} \text { ) }\end{array}$ \\
\hline \multicolumn{6}{|c|}{ LIVER } \\
\hline HK & $0.011 \pm 0.002$ & $0.020 \pm 0.003^{*}$ & $0.011 \pm 0.001^{*}$ & $0.014 \pm 0.002^{*}$ & $0.013 \pm 0.001^{*}$ \\
\hline PGI & $0.063 \pm 0.010$ & $0.116 \pm 0.022^{*}$ & $0.062 \pm 0.005^{*}$ & $0.076 \pm 0.011^{*}$ & $0.070 \pm 0.011^{*}$ \\
\hline $\mathrm{SDH}$ & $1.703 \pm 0.18$ & $0.422 \pm 0.08^{*}$ & $1.325 \pm 0.21^{*}$ & $0.672 \pm 0.05^{\star}$ & $1.040 \pm 0.07^{*}$ \\
\hline $\mathrm{MDH}$ & $1.748 \pm 0.13$ & $0.418 \pm 0.03^{*}$ & $1.263 \pm 0.32^{*}$ & $0.623 \pm 0.07^{*}$ & $1.098 \pm 0.05^{*}$ \\
\hline G-6-Pase & $0.367 \pm 0.06$ & $0.173 \pm 0.04^{*}$ & $0.344 \pm 0.03^{*}$ & $0.289 \pm 0.04^{*}$ & $0.314 \pm 0.01^{*}$ \\
\hline F-1, 6-BPase & $0.281 \pm 0.05$ & $0.136 \pm 0.03^{*}$ & $0.264 \pm 0.02^{*}$ & $0.200 \pm 0.02^{*}$ & $0.243 \pm 0.02^{*}$ \\
\hline \multicolumn{6}{|c|}{ BREAST } \\
\hline $\mathrm{HK}$ & $0.045 \pm 0.006$ & $0.072 \pm 0.012^{*}$ & $0.047 \pm 0.004^{*}$ & $0.051 \pm 0.004^{*}$ & $0.049 \pm 0.003^{*}$ \\
\hline PGI & $0.040 \pm 0.018$ & $0.124 \pm 0.020^{*}$ & $0.041 \pm 0.017^{*}$ & $0.085 \pm 0.017^{*}$ & $0.052 \pm 0.020^{*}$ \\
\hline $\mathrm{SDH}$ & $1.197 \pm 0.18$ & $0.337 \pm 0.03^{*}$ & $1.042 \pm 0.17^{*}$ & $0.602 \pm 0.05^{*}$ & $0.933 \pm 0.08^{*}$ \\
\hline $\mathrm{MDH}$ & $6.568 \pm 0.96$ & $1.827 \pm 0.51^{*}$ & $5.938 \pm 0.89^{*}$ & $3.642 \pm 0.70^{*}$ & $5.068 \pm 0.43^{*}$ \\
\hline G-6-Pase & $0.227 \pm 0.01$ & $0.071 \pm 0.04^{*}$ & $0.194 \pm 0.01^{*}$ & $0.147 \pm 0.03^{*}$ & $0.176 \pm 0.02^{*}$ \\
\hline F-1, 6-BPase & $0.746 \pm 0.07$ & $0.385 \pm 0.10^{*}$ & $0.688 \pm 0.08^{*}$ & $0.586 \pm 0.04^{*}$ & $0.639 \pm 0.04^{*}$ \\
\hline
\end{tabular}

Values are expressed as mean \pm SD for six rats in each group. *p<0.05. Group I vs Group II, Group II vs Group III, Group IV and Group V. Units: HK- $\mu$ moles of glucose 6 phosphate formed/min/mg protein; PGI - $\mu$ moles of fructose formed/min/mg protein; SDH - $\mu$ moles of succinate oxidized /min/mg protein; MDH $\mu$ moles of NADH oxidized/min/mg protein; G-6-Pase and F-1, 6- BPase - $\mu$ moles of phosphorous liberated/min $/ \mathrm{mg}$ protein

\begin{tabular}{|c|c|c|c|c|c|}
\hline Parameter & $\begin{array}{l}\text { Group I } \\
\text { (Control) }\end{array}$ & $\begin{array}{l}\text { Group II } \\
\text { (DMBA) }\end{array}$ & $\begin{array}{c}\text { Group III } \\
\text { (DMBA+CP) }\end{array}$ & $\begin{array}{c}\text { Group IV } \\
\text { (DMBA + HEEPS } \\
200 \mathrm{mg} / \mathrm{kgbw} \text { ) }\end{array}$ & $\begin{array}{c}\text { Group V } \\
\text { (DMBA + HEEPS } 400 \\
\mathrm{mg} / \mathrm{kgbw})\end{array}$ \\
\hline \multicolumn{6}{|c|}{ LIVER } \\
\hline POR & $20.038 \pm 0.33$ & $8.795 \pm 0.58^{*}$ & $15.780 \pm 0.28^{*}$ & $11.612 \pm 0.31^{*}$ & $13.098 \pm 0.52^{*}$ \\
\hline $\operatorname{cox}$ & $223.143 \pm 1.18$ & $49.810 \pm 5.39^{*}$ & $160.650 \pm 1.63^{*}$ & $135.670 \pm 6.15^{*}$ & $151.075 \pm 7.01^{*}$ \\
\hline GST & $52.800 \pm 1.29$ & $22.118 \pm 1.71^{*}$ & $43.463 \pm 1.24^{*}$ & $36.803 \pm 1.15^{*}$ & $39.868 \pm 1.94^{*}$ \\
\hline \multicolumn{6}{|c|}{ BREAST } \\
\hline POR & $11.680 \pm 1.54$ & $3.605 \pm 0.89^{*}$ & $9.587 \pm 1.48^{*}$ & $6.750 \pm 1.59^{*}$ & $7.817 \pm 1.07^{*}$ \\
\hline $\operatorname{cox}$ & $475.923 \pm 8.57$ & $161.510 \pm 8.81^{*}$ & $412.637 \pm 6.48^{*}$ & $292.653 \pm 6.37^{*}$ & $372.192 \pm 7.27^{*}$ \\
\hline GST & $43.742 \pm 5.27$ & $21.300 \pm 5.86^{*}$ & $37.872 \pm 6.18^{*}$ & $31.813 \pm 2.32^{*}$ & $35.908 \pm 4.19^{*}$ \\
\hline
\end{tabular}

Values are expressed as mean \pm SD for six rats in each group. * $p<0.05$. Group I vs Group II, Group II vs Group III, Group IV and Group V. Units: POR - $\mu$ moles of Cytochrome reduced/min/mg protein; COX - $\mu$ moles of Cytochrome oxidised/min/mg protein; GST - $\mu$ moles of CDNB conjugation formed/min/mg protein 
Table 3: Phytochemical compounds identified through the GC-MS study of HEEPS

\begin{tabular}{|c|c|c|c|c|}
\hline $\begin{array}{l}\text { SI. } \\
\text { No }\end{array}$ & $\begin{array}{l}\text { Retention } \\
\text { Time (min) }\end{array}$ & Compound & $\begin{array}{l}\text { Molecular } \\
\text { Formula }\end{array}$ & $\begin{array}{c}\text { Molecula } \\
\text { Weight }\end{array}$ \\
\hline 1 & 9.940 & 3,7- Dimethylnonane & $\mathrm{C}_{11} \mathrm{H}_{24}$ & 156 \\
\hline 2 & 12.553 & Silane, trimethyl (1-methyl dodecyl oxy)- & $\mathrm{C}_{16} \mathrm{H}_{36} \mathrm{OSi}$ & 272 \\
\hline 3 & 14.552 & 1,3-Di isopropoxy-1,3-dimethyl-1,3-disilacyclobutane & $\mathrm{C}_{10} \mathrm{H}_{24} \mathrm{O}_{2} \mathrm{Si}_{2}$ & 232 \\
\hline 4 & 15.935 & Sym-tetra (isopropyl) disiloxane & $\mathrm{C}_{12} \mathrm{H}_{30} \mathrm{OSi}_{2}$ & 246 \\
\hline 5 & 16.569 & a Curcumene & $\mathrm{C}_{15} \mathrm{H}_{22}$ & 202 \\
\hline 6 & 17.318 & a Bergamotene & $\mathrm{C}_{15} \mathrm{H}_{24}$ & 204 \\
\hline 7 & 22.830 & Butyldimethyl (2-styryl[1,3]dithian-2-yl) silane & $\mathrm{C}_{18} \mathrm{H}_{28} \mathrm{~S}_{2} \mathrm{Si}_{2}$ & 336 \\
\hline 8 & 23.575 & 6-Methyl-6-(5-methylfuran-2-yl) heptan-2-one & $\mathrm{C}_{13} \mathrm{H}_{20} \mathrm{O}_{2}$ & 208 \\
\hline 9 & 24.556 & 1,1,3,3-Tetramethylcyclopentane & $\mathrm{C}_{9} \mathrm{H}_{18}$ & 126 \\
\hline 10 & 25.760 & 5-Isopropenyl-2-methyl-7-oxabicyclo[4.1.0]heptan-2-ol & $\mathrm{C}_{10} \mathrm{H}_{16} \mathrm{O}_{2}$ & 168 \\
\hline 11 & 26.954 & $\begin{array}{l}\text { 3,7,11,15-Tetramethyl-2-hexadecen-1-ol } \\
\text { (Synonym: Phytol) }\end{array}$ & $\mathrm{C}_{20} \mathrm{H}_{40} \mathrm{O}$ & 296 \\
\hline 12 & 27.083 & Hexahydrofarnesyl acetone & $\mathrm{C}_{18} \mathrm{H}_{36} \mathrm{O}$ & 268 \\
\hline 13 & 27.425 & $\begin{array}{l}\text { 3,7,11,15-Tetramethyl-2-hexadecen-1-ol } \\
\text { (Synonym: Phytol) }\end{array}$ & $\mathrm{C}_{20} \mathrm{H}_{40} \mathrm{O}$ & 296 \\
\hline 14 & 27.749 & $\begin{array}{l}\text { 3,7,11,15-Tetramethyl-2-hexadecen-1-ol } \\
\text { (Synonym: Phytol) }\end{array}$ & $\mathrm{C}_{20} \mathrm{H}_{40} \mathrm{O}$ & 296 \\
\hline 15 & 28.337 & Hexahydrofarnesyl acetone & $\mathrm{C}_{18} \mathrm{H}_{36} \mathrm{O}$ & 268 \\
\hline 16 & 28.519 & Hexadecanoic acid, methyl ester & $\mathrm{C}_{17} \mathrm{H}_{34} \mathrm{O}_{2}$ & 270 \\
\hline 17 & 28.725 & 2-Octenoic acid, 4-isopropylidene-7-methyl-6-methylene-, methyl ester & $\mathrm{C}_{14} \mathrm{H}_{22} \mathrm{O}_{2}$ & 222 \\
\hline 18 & 28.875 & 1-Hexadecen-3-ol, 3,7,11,15-tetramethyl- (Synonym: Isophytol) & $\mathrm{C}_{20} \mathrm{H}_{40} \mathrm{O}$ & 296 \\
\hline 19 & 29.585 & Ethyl heptadecanoate & $\mathrm{C}_{19} \mathrm{H}_{38} \mathrm{O}_{2}$ & 298 \\
\hline 20 & 31.021 & 9,12-Octadecadienoic acid (Z,Z)-, methyl ester & $\mathrm{C}_{19} \mathrm{H}_{34} \mathrm{O}_{2}$ & 294 \\
\hline 21 & 31.090 & 9-Octadecenoic acid (Z)-, methyl ester & $\mathrm{C}_{19} \mathrm{H}_{36} \mathrm{O}_{2}$ & 296 \\
\hline 22 & 31.158 & 9-Octadecenoic acid (Z)-, methyl ester & $\mathrm{C}_{19} \mathrm{H}_{36} \mathrm{O}_{2}$ & 296 \\
\hline 23 & 31.260 & $\begin{array}{l}\text { 3,7,11,15-Tetramethyl-2-hexadecen-1-ol } \\
\text { (Synonym: Phytol) }\end{array}$ & $\mathrm{C}_{20} \mathrm{H}_{40} \mathrm{O}$ & 296 \\
\hline 24 & 31.416 & Octadecanoic acid, methyl ester & $\mathrm{C}_{19} \mathrm{H}_{38} \mathrm{O}_{2}$ & 298 \\
\hline 25 & 32.256 & Ethyl octadecanoate & $\mathrm{C}_{20} \mathrm{H}_{40} \mathrm{O}_{2}$ & 312 \\
\hline 26 & 33.469 & Eicosane & $\mathrm{C}_{20} \mathrm{H}_{42}$ & 282 \\
\hline 27 & 34.216 & 5-methyl-5-(4,8,12-trimethyltridecyl)oxolan-2-one & $\mathrm{C}_{21} \mathrm{H}_{40} \mathrm{O}_{2}$ & 324 \\
\hline 28 & 34.675 & Dotriacontane & $\mathrm{C}_{32} \mathrm{H}_{66}$ & 450 \\
\hline 29 & 35.128 & Nopol & $\mathrm{C}_{11} \mathrm{H}_{18} \mathrm{O}$ & 166 \\
\hline 30 & 36.093 & Hexatriacontane & $\mathrm{C}_{36} \mathrm{H}_{74}$ & 506 \\
\hline 31 & 37.021 & Mono (2-ethylhexyl)phthalate & $\mathrm{C}_{16} \mathrm{H}_{22} \mathrm{O}_{4}$ & 278 \\
\hline 32 & 37.830 & Tetrapentacontane & $\mathrm{C}_{54} \mathrm{H}_{110}$ & 758 \\
\hline 33 & 40.005 & Tetrapentacontane & $\mathrm{C}_{54} \mathrm{H}_{110}$ & 758 \\
\hline 34 & 41.807 & Methyl steviol & $\mathrm{C}_{21} \mathrm{H}_{32} \mathrm{O}_{3}$ & 332 \\
\hline 35 & 42.527 & 1-Bromotriacontane & $\mathrm{C}_{30} \mathrm{H}_{61} \mathrm{Br}$ & 501 \\
\hline 36 & 43.190 & Docosa-2,6,10,14,18-pentaen-22-al, 2,6,10,15,18-pentamethyl-, all trans & $\mathrm{C}_{27} \mathrm{H}_{44} \mathrm{O}$ & 384 \\
\hline 37 & 44.416 & Stigmast-5-en-3-ol, (3 beta) (Synonym: $\beta$ Sitosterol) & $\mathrm{C}_{29} \mathrm{H}_{50} \mathrm{O}$ & 414 \\
\hline 38 & 45.783 & 5-Nitrobenzofuran-2-one & $\mathrm{C}_{8} \mathrm{H}_{5} \mathrm{NO}_{4}$ & 179 \\
\hline 39 & 46.823 & Cedrol & $\mathrm{C}_{15} \mathrm{H}_{26} \mathrm{O}$ & 222 \\
\hline
\end{tabular}


molecular oxygen to water in the terminal complex of mitochondrial respiratory chain. ${ }^{49}$ In the present study reduction in the activity of the enzyme was found in DMBA induced breast cancer. Defective complex IV has been observed in various studies conducted in many human tumors and mouse xenografts. ${ }^{50}$ The activity of the enzyme was significantly increased in the treatment groups indicating the capability of $P$. scandens extract to repair the mitochondrial membrane damage. Similar results were observed in the studies conducted using tangeretin in breast cancer bearing rats. ${ }^{51}$

GST is a major group of phase II enzymes for which glutathione is the substrate. The expression of GST is controlled by multiple transcription factors and is highly inducible by dietary components. ${ }^{52}$ The enzyme is involved in the detoxification of variety of xenobiotics and also plays an important role in carcinogen detoxification. ${ }^{53,54}$ In the present study, the level of GST was decreased in carcinoma bearing rats depicting the deleterious effect of carcinogen. P. scandens extract treated groups showed near normal activity showing curative effect of the plant extract. Chemopreventive compounds act as blocking agents that affect the initiation phase of cancer by detoxification of carcinogen through increasing the activity of GST. ${ }^{55}$ Our results are in accordance with the above findings as we have observed a significant decline in the activity of GST in DMBA induced cancer bearing animals (Group II) and a significant increase in the activity of the enzyme in treatment groups.

The HEEPS contains rich phytochemicals which was identified by GC-MS analysis. In the present study in terms of percentage phytol, $\beta$-sitosterol, hexadecanoic acid methyl ester, octadecanoic acid methyl esters were predominant in the extract. Phytol has been reported to have anticancer ${ }^{56}$, antimicrobial ${ }^{57}$, diuretic and antiinflammatory activity. ${ }^{58} \beta$-sitosterol has been reported to impart protection to cells against damage by reactive oxygen species by increasing the activities of antioxidant enzymes. ${ }^{59}$ Also it was pointed out in the study of Awad et al. ${ }^{60}$ that $\beta$-sitosterol can alleviate cancer development by reducing production of carcinogens and its treatment has reduced the breast cancer cell growth. ${ }^{61}$ Hexadecanoic acid methyl ester was reported to have anticancer and antioxidant properties and octadecanoic acid has been reported to have anticancer, antioxidant antibacterial, antifungal, hypocholesterolemic, antihistamic and anticoronary properties. ${ }^{62}$ Apart from these, remaining compounds mentioned in Table 3 detected by GC-MS has been reported to have significant application in drug industry.

\section{CONCLUSION}

Damage to the mitochondrial membrane and increased rate of glycolytic enzymes during cancer is an important field of research in breast cancer studies. From the present study, it was evident that significant damage was caused to mitochondria in breast cancer induced animals which resulted in an increase in the glycolytic enzymes and a decrease in the level of TCA cycle, gluconeogenic enzymes. Also it was found that the levels of marker enzymes such as POR, COX and GST were also altered in breast cancer induced animals. All the altered enzyme activities were brought to near normal activity in plant extract treated groups which suggest the potential therapeutic effect of the plant. The GC-MS analysis of the plant also well supported the fact that the plant contained important compound which could be employed for the treatment of breast cancer. To the best of our knowledge, this is the first publication about the therapeutic activity of $P$. scandens extract against breast cancer. However, compounds responsible for its anticancer property and its mode of action need further study.

\section{CONFLICT OF INTEREST}

The authors declare that there are no conflicts of interest.

\section{ABBREVIATION USED}

HEEPS: $50 \%$ hydro-ethanolic extract of Pothos scandens; DMBA: 7, 12 -Dimethylbenz [a] anthracene; CP: Cyclophoshamide; HK: Hexokinase; PGI: Phosphogluco isomerase; SDH: Succinate dehydrogenase; MDH: Malate dehydrogenase; G-6-Pase: Glucose6-phosphatase; F-1,6-BPase: Fructose-1,6-bis phosphatase; POR: Cytochrome P450 reductase; COX: Cytochrome C oxidase; GST: Glutathione -S- transferase; NIST: National Institute of Standard and Technology; SPSS: Statistical Package of Social Sciences; OXPHOS: Oxidative phosphorylation.

\section{REFERENCES}

1. Kaufman D and Chabner BA, Clinical strategies for cancer treatment: The Role of drugs. In: Cancer chemotherapy and biotherapy: Principle and practice, Chabner, B.A. and D.L. Longo (Ed.). Lippincott-Raven, Philadelphia. 1996;1-16. PMid:10155984.

2. Karthikeyan R, Karthigayan S, Sri Balasubashi M, Vijayalakshni $S$ and Balasubramanian T, Antitumor effect of snake venom (Hydrophis spiralis) on ehrlich ascites carcinoma bearing mice. Int. J. Cancer Res. 2007;s3:167-73.

3. Smigal C, Jemal A, Ward E, Cokkinides V, Smith R., Howe H, et al., Trends in breast cancer by race and ethnicity: Update. CA Cancer J Clin. 2006;56:106-30. https://doi.org/10.3322/canjclin.56.3.168; PMid:16514137.

4. Russo J, Yang $X$ and $\mathrm{Hu}$ Y, Biological and molecular basis of human breast cancer. Frontiers Biosci. 1998;3:944-60. https://doi.org/10.2741/A335. 
5. Yadav $P$ and Jaroli DP, Breast cancer: awareness and risk factors in collegegoing younger age group women in Rajasthan. Asian Pac J Cancer Prev. 2010;11(2):319-22. PMid:20843108.

6. Guo $\mathrm{J}$ and Wang $\mathrm{MH}$, Extract of Ulmus davidiana planch barks induced apoptosis in human hepatoma cell line HEPG2. Exp Clin Sci J. 2009;8:130-7.

7. Vargo-Gogola T and Rosen JM, Modelling breast cancer: one size does not fit all. Nat Rev Cancer. 2007;7(9):659-72. https://doi.org/10.1038/nrc2193; PMid:17721431.

8. Warburg O, On the origin of cancer cells. Science. 1956;123(3191):309-14. https://doi.org/10.1126/science.123.3191.309.

9. Ma Y, Bai RK, Trieu R and Wong LJ, Mitochondrial dysfunction in human breast cancer cells and their transmitochondrial cybrids. Biochimica et Biophysica Acta. 2010;1797(1):29-37. https://doi.org/10.1016/j.bbabio.2009.07.008 PMid:19647716 PMCid:PMC2787670.

10. Saalu LC, Ajayi GO and Adeneye AA, Ethanolic seed extracts of grapefruit (Citrus paradise Macfad) on an effective attenuator of Doxorubicin-induced oxidase stress in the rat heart. Int. J. Cancer Res. 2009;5(2):44-52. https:// doi.org/10.3923/ijcr.2009.44.52.

11. Jeyachandran $R$, Mahesh $A$ and Cindrella $L$, DEN- Induced cancer and its alleviation by Anisomeles malabarica (L.) R.Br. ethanolic leaf extract in male albino mice. Int. J. Cancer Res. 2007;3:174-9. https://doi.org/10.3923/ ijcr.2007.174.179.

12. Cai $\mathrm{Y}$, Luo $\mathrm{Q}$, Sun $\mathrm{M}$, et al., Antioxidant activity and phenolic compounds of 112 traditional Chinese medicinal plants associated with anticancer. Life Sci. 2004;74(17):2157-84. https://doi.org/10.1016/j.lfs.2003.09.047;। PMid:14969719.

13. Sangwoo L, Chunjie $X$ and Shengji $P$, Ethnobotanical survey of medicinal plants at periodic markets of honghe prefecture in Yunnan Province, SW China. J Ethnopharmacol. 2008;117(2):362-77.https://doi.org/10.1016/j. jep.2008.02.001; PMid:18359178

14. Baharuddin S and Mansor M, Medicinal aroids conservation: A case study of floral garden School of Biological Scie Ces, Universiti Sains Malayasia. Proceedings of the 4th IMT-GT UNINET Conference. 2002; 216-9.

15. Bhandary MJ, Chandrashekar KR and Kaveriappa KM, Medical ethnobotany of the Siddis of Uttara Kannada district, Karnataka, India. J Ethnopharmacol. 1995;47(3):149-58. https://doi.org/10.1016/0378-8741(95)01274-H.

16. Das AK, Dutta BK and Sharma GD, Medicinal plants used by different tribes of Cachar district, Assam. Indian J Tradit Knowl. 2008;7:446-54.

17. Sainuddin T and Mohammed HKP, Formulation \& pharmacological evaluation of herbal gel of Pothos Scandens Linn. WebmedCentral WOUND HEALING. 2010; 1:WMC001344.

18. Sajeesh $\mathrm{T}$, Arunachalam $\mathrm{K}$ and Parimelazhagan $\mathrm{T}$, Antioxidant and antipyretic studies on Pothos scandens L. Asian Pacific J Tropical Med, 2011; 4: 889-99. https://doi.org/10.1016/S1995-7645(11)60214-9.

19. Gupta S, Duraiswamy B and Satishkumar MN, Peritoneal mast cell stabilization potential of Pothos scandens L. Indian J.Pharmacol. 2013;45(1):83-6. https:// doi.org/10.4103/0253-7613.106442; PMid:23542883 PMCid:PMC3608302

20. Yusuf ATM, Rashid MMU, Hassan MM, Sayeed MA and Jainul MA, In-vitro Cytotoxic and thrombolytic potential of Pothos scandens L. J. Pharmacogn. Phytochem. 2013;2(1):193-8.

21. Lalitharani, Mohan VR, Maruthupandian, Pharmacognostical and phytochemical studies on Pothos scandens L. Int J Phytomed, 2010;2:277-83.

22. Lalitharani S, Mohan VR, Regini GS and Kalidass C, GC-MS analysis of ethanol extract of Pothos scandens leaf. J Herb Med Toxicol, 2009;3:159-60.

23. Angkhana I, Shengji P, Balslev H, Wong PW and Trisonthi C, A comparitive study on medicinal plants used in Akha's traditional medicine in China and Thailand, cultural coherence or ecological divergence? J Ethnopharmacol. 2008;116:508-17. https://doi.org/10.1016/j.jep.2007.12.015; PMid:18280071

24. Branstrup N, Krik JE and Bruni C, The hexokinase and phosphoglucomerase activities of aorta and pulmonary artery tissue in individuals of various ages. J Gerontol. 1957;12(2):166-71. https://doi.org/10.1093/geronj/12.2.166.

25. Horrocks JE, Ward $\mathrm{J}$ and Kind J, A routine method for the determination of phosphoglucoisomerase activity in body fluid. J Clin Pathol. 1963;16(3):248-51. https://doi.org/10.1136/jcp.16.3.248

26. King J, The hydrolases-acid and alkaline phosphatases. In: Practical clinical Enzymology, Van,D (Ed.), Norstand company Limited, London. 1965b;191-208.

27. Gancedo JM and Gancedo C, Fructose-1,6-biphosphatase, Phosphofructokinase and Glucose-6-phosphodehydrogenase. Proc.SOC.EXP.Biol. Med. 1971;106:607-9.

28. Slater EC and Bonner WD, The effect of fluoride on the succinic oxidase system. Biochem J. 1952; 52(2):185-96. https://doi.org/10.1042/bj0520185.
29. Mehler AH, Kornberg A, Grisolia S and Ochoa S, The enzymatic mechanism of oxidation- reductions between malate or isocitrate or pyruvate. J Biol Chem. 1948;174:s961-77.

30. Masters BS, Williams $\mathrm{CH}$ and Kamin $\mathrm{H}$, The preparation and properties of microsomal TPNH cytochrome c reductase from pig liver. In: Estabrook, R.W., Pullman, M.E. eds: Methods Enzymol. 1967;10:565-73.https://doi. org/10.1016/0076-6879(67)10098-0.

31. Wharton DC and Tzagoloff A, Cytochrome oxidase from beef heart mitochondria. Methods Enzymol. 1967;10:245-50. https://doi.org/10.1016/ 0076-6879(67)10048-7.

32. Habig WH and Jakoby WB, Glutathione S-transferases. The first enzymatic step in mercapturic acid formation. J. Bio. Chem. 1974;249(22):7130-9.

33. Heimann R., Heuson JC and Coune A, Tumors developing in oophorectomized Sprague-Dawley rats after a single gastric instillation of 7,12-dimethylbenz(a) anthracene. Cancer Res. 1968;28(2):309-13. PMid:5641521.

34. Bhuvaneswari V, Velmurugan B, Abraham SK and Nagini S, Tomato and garlic by gavage modulate 7,12 -dimethylbenz[a]anthracene-induced genotoxicity and oxidative stress in mice. Braz J Med Biol Res. 2004; 37(7):1029-34. https://doi.org/10.1590/S0100-879X2004000700012.

35. Esterbauer $\mathrm{H}$, Estimation of peroxidative damage. Pathol Biol (Paris). 1996;44:25-8.

36. Yeung SJ, Pan J and Lee MH, Roles of p53, MYC and HIF-1 in regulating glycolysis: the seventh hallmark of cancer. Cell Mol Life Sci. 2008;65(24):398199. https://doi.org/10.1007/s00018-008-8224-x; PMid:18766298.

37. DeBerardinis R.J, Lum JJ, Hatzivassiliou G and Thompson CB, The biology of cancer:metabolic reprogramming fuels cell growth and proliferation. Cell Metab. 2008 7(1):11-20. https://doi.org/10.1016/j.cmet.2007.10.002; PMid:18177721.

38. DeBerardinis R.J, Sayed N, Ditsworth D and Thompson CB, Brick by brick: metabolism and tumor cell growth. Curr. Opin. Genet. Dev. 2008b;18(1):54-61. https://doi.org/10.1016/j.gde.2008.02.003 PMid:18387799 PMCid:PMC2476215

39. Parry DM and Pedersen PL, Intracellular localization and properties of particulate hexokinase in the Novikoff ascites tumour. Evidence for an outer mitochondrial membrane location. J Biol Chem. 1983;258:10904-12. PMid:6885806

40. Parveen V, Sharma DC and Shastri KD. A clinicobiochemical study of phosphohexose-isomerase, aliesterate and sulphyhydryl group in 25 normal and 35 cancer patients. Indian J cancer. 1974;43:448-56.

41. Dimitrova-Shumkovska J, Veenman L, Ristoski T, et al., Decreases in binding capacity of the mitochondrial $18 \mathrm{kda}$ translocator protein accompany oxidative stress and pathological signs in rat liver after DMBA exposure. Toxicol Pathol. 2010;38(6):957-68. https://doi.org/10.1177/0192623310379137; PMid:21037200

42. Hennipman A, Oirschot BAV, Smits J, Rijksen G and Staal GE, Glycolytic enzyme activities in breast cancer metastases. Tumour Biol. 1988;9(5):241-8. https://doi.org/10.1159/000217568

43. Wang B, Hsu SH, Frankel W, et al., Stat3-mediated activation of microRNA23a suppresses gluconeogenesis in hepatocellular carcinoma by downregulating glucose-6-phosphatase and peroxisome proliferator- activated receptor gamma, coactivator 1 alpha. Hepatology. 2012;56(1):186-97. https://doi.org/10.1002/hep.25632; PMid:22318941 PMCid:PMC3355233

44. Chen L, Yu LJ and Waxman DJ, Potentiation of cytochrome P450/ cyclophosphamide-based cancer gene therapy by coexpression of the P450 reductase gene. Cancer Res. 1997;57(21):4830-7. PMid:9354446.

45. Chiocca EA and Waxman DJ, Cytochrome P450-based gene therapies for cancer. Methods Mol Med. 2004;90:203-22. PMid:14657565

46. Portsmouth D, Hlavaty J and Renner M, Suicide genes for cancer therapy. Mol Aspects Med. 2007;28(1):4-41. https://doi.org/10.1016/j.mam.2006.12.001; PMid:17306358

47. Chen $L$ and Waxman DJ, Cytochrome P450 gene-directed enzyme prodrug therapy (GDEPT) for cancer. Curr Pharm Des. 2002;8(15):1405-16. https:// doi.org/10.2174/1381612023394566.

48. Kan O, Kingsman S and Naylor S, Cytochrome P450-based cancer gene therapy: current status. Expert Opin Biol Ther. 2002;2(8):857-68. https://doi. org/10.1517/14712598.2.8.857; PMid:12517265

49. Van Kuilenburg ABP, Dekker HL, Van Den Boget C, Nieboer P, Van Gelder BP and Muijsers AO, Isoforms of human cytochrome c oxidase. Subunit composition and steady-state kinetic properties. Eur. J. Biochem. 1991;109(3):615-22. https://doi.org/10.1111/j.1432-1033.1991.tb16162.x.

50. Wallace DC, Mitochondria and cancer. Nat Rev Cancer. 2012; 12: 685-98. https://doi.org/10.1038/nrc3365; PMid:23001348 PMCid:PMC4371788 
51. Periyasamy K, Sivabalan V, Baskaran K, Kasthuri K and Sakthisekaran D, Cellular metabolic energy modulation by tangeretin in 7, 12-dimethylbenz (a) anthracene-induced breast cancer. J Biomed Res. 2016;30(2):134-41. PMid:28276668 PMCid:PMC4820890.

52. Pool-Zobel B, Veeriah $S$ and Bohmer FD, Modulation of xenobiotic metabolising enzymes by anticarcinogens -focus on glutathione S-transferases and their role as targets of dietary chemoprevention in colorectal carcinogenesis. Mutat Res. 2005;591(1):74-92. https://doi. org/10.1016/j.mrfmmm.2005.04.020; PMid:16083918.

53. King R.S, Teitel $\mathrm{CH}$, Shaddock JG, Casciano DA and Kadlubar FF, Detoxification of carcinogenic aromatic and heterocyclic amines by enzymatic reduction of the N-hydroxy derivative. Cancer Lett. 1999;143(2):167-71. https://doi.org/10.1016/S0304-3835(99)00119-6.

54. Sato K, Glutathione s-transferase as markers of preneoplasia and neoplalsia. Adv Cancer Res. 1989;52:205-55. https://doi.org/10.1016/S0065230X(08)60214-6. s

55. Russo J, Hu Y, Yang X and Russo IX, Developmental, Cellular, and Molecular Basic of Human Breast Cancer. J. Of National Cancer Institut Monographs. 2000;27:17-37. https://doi.org/10.1093/oxfordjournals.jncimonographs.a024241.

56. Daniet AO, Folahan OA, Ayele G, Adrian A, Ernest BI, Broderick E, et al., Biological Activity and Mass Spectrometric Analysis of Vernonia amygdalina Fractions. J Biosci Technol. 2011;2(3)S:287-304
57. Inoue Y, Hada TA, Shiraishi K., Hirore H, Hamashima and Kobayashi S, Biphasic effects of Geranylgeraniol, Terpenone and Phytol on the growth of Staphylococcus aureus. Antimicrob. Agents Chemother. 2005;49(5):1770-4. https://doi.org/10.1128/AAC.49.5.1770-1774.2005; PMid:15855494 PMCid: PMC1087616.

58. Sermakkani M and Thangapandian V, GC-MS analysis of Cassia italica leaf methanol extract. Asian J Pharm Clin Res. 2012;5(2):90-4.

59. Vivancos $\mathrm{M}$ and Moreno $\mathrm{JJ}, \beta$-Sitosterol modulates antioxidant enzyme response in RAW 2647 macrophages. Free Radic Biol Med. 2005;39(1):91-7. https://doi.org/10.1016/j.freeradbiomed.2005.02.025; PMid:15925281

60. Awad AB, Toczek J and Fink CS, Phytosterols decrease prostaglandin release in cultured P388D1/MAB macrophages. Prostaglandins Leukotrienes Essent. Fatty Acids. 2004;70(6):511-20. https://doi.org/10.1016/j.plefa.2003.11.005; PMid:15120714.

61. Awad AB, Chinnam M, Fink CS and Bradford PG, $\beta$-Sitosterol activates Fas signaling in human breast cancer cells. Phytomedicine. 2007;14(11):747-54. https://doi.org/10.1016/j.phymed.2007.01.003; PMid:17350814.

62. Kumar PP, Kumaravel S and Lalitha C, Screening of antioxidant activity, total phenolics and GC-MS study of Vitex negundo. African J Biochem Res. 2010;4(7):191-5.

\section{SUMMARY}

- The whole aerial parts of Pothos scandens were not evaluated for its anticancer properties though it was used by traditional healers to treat cancer.

- The present study investigated the therapeutic effect of $50 \%$ hydro-ethanolic extract of aerial parts of Pothos scandens (HEEPS) on key carbohydrate metabolizing enzymes (glycolytic [Hexokinase, Phosphogluco isomerase], gluconeogenic [Glucose-6-phosphatase, Fructose-1,6-bis phosphatase]) and TCA cycle [Succinate dehydrogenase, Malate dehydrogenase] and xenobiotic marker (Cytochrome P450 reductase, Cytochrome $\mathrm{C}$ oxidase and Glutathione -S- transferase) enzymes in DMBA induced experimental mammary carcinoma.

- HEEPS showed significant anticancer activity which was revealed by its ability to restore the enzymes levels which were altered in cancer induced groups to near normal in HEEPS treated groups. The phytochemical analysis of HEEPS also showed the presence of compounds with proved anticancer activity.

\section{About Authors}

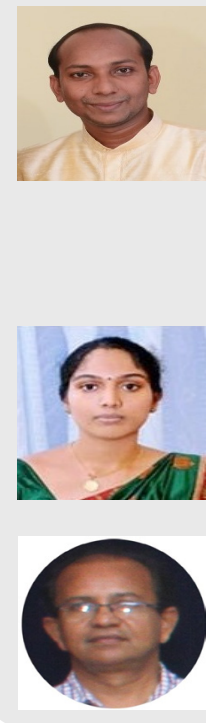

Mr. Jethinlalkhosh J P: Is working as Quality Control Assistant in Food Corporation of India, Palakkad, Kerala, India. Prior to that, he worked as an Assistant Professor, Department of Biotechnology and Applied Microbiology, St. Thomas College, Pala, Kottayam, Kerala, India. Currently he is pursuing his Ph. D from Department of Biochemistry, Research and Development Centre, Bharathiar University, Coimbatore, Tamil Nadu, India, under the guidance of DR. D Victor Arokia Doss. He is having research experience in the field of Phytochemistry, Pharmacology, Clinical Biochemistry and Toxicology, Molecular Biology and Cancer Biology and is having publications in many international peer reviewed journals.

Mrs. P Praveena: Is presently working as Assistant Professor, Department of Biotechnology, Sahrdaya college of Engineering and Technology, Thrissur, Kerala. Currently she is pursuing her Ph. D from Department of Biochemistry, Research and Development Centre, Bharathiar University, Coimbatore, Tamil Nadu, India, under the guidance of DR. D Victor Arokia Doss. Her major research area and publications are in the field of Biochemistry, Clinical toxicology and Phytochemistry.

Dr. Victor Arokia Doss: Is working as an Associate Professor in the Department of Biochemistry, P S G Arts and Science College, Coimbatore, Tamil Nadu, India since 1994. He has research experience in the field of Clinical Biochemistry and Toxicology, Molecular Biology, Cancer Biology, Immunology, Protein Chemistry and Bioinformatics. Over the years he has authored and coauthored more than 80 research articles in international peer reviewed journals.

Cite this article: Prasannakumari JJ, Padmam P, Doss VA. Therapeutic Effect of Hydro-Ethanolic Extract of Pothos scandens L on key Carbohydrate Metabolizing Enzymes and Xenobiotic Marker Enzymes in DMBA Induced Experimental Mammary Carcinoma. Indian J of Pharmaceutical Education and Research. 2017;51(3):418-26. 